Лілія Дергачова

доктор історичних наук, доктор історичних наук, старший науковий співробітник Нумізматичний Кабінет, Бібліотека

Академії Наук Румунії

(Бухарест, Румунія)
Lilia Dergaciova

$\mathrm{PhD}, \mathrm{PhD}$, Senior Research fellow

The Numismatic Department at

Library of The Romanian Academy

(Bucarest, Romania)

dergaciova.lili@gmail.com

Андрій Бойко-Гагарін

доктор історичних наук, старший зберігач фондів відділу

«Музей грошей»

Управління зв'язків 3

громадськістю та фінансової обізнаності,

Департамент комунікацій,

Національний Банк України, доцент кафедри мистецтвознавчої експертизи ім. Казимира Малевича,

Національна академія керівних

кадрів культури і мистецтв

(Київ, Україна)
Andrii Boiko-Haharin

doctor of history (dr. habil), the senior treasurer «Museum of money»,

National bank of Ukraine associate professor of art expertise university department,

National academy of managing staff of culture and arts (Kyiv, Ukraine)

ORCID: 0000-0003-4610-3665

ResearcherID: n-6985-2017

boiko.gagarin@ukr.net

«ШТРИХИ ДО ПОРТРЕТУ» ГРОШОВОГО ОБІГУ СЕРЕДНЬОВІЧНИХ МОНЕТ НА ТЕРИТОРІЇ УКРАЇНИ (I)

\title{
MEDIEVAL COINS ON THE TERRITORY OF UKRAINE. "BRUSH STROKES” TO THE MONETARY CIRCULATION (I)
}

\section{Summary.}

During the past two decades, with the development of private search using a special equipment, the number of known coins has increased dramatically, opening up the new opportunities for researchers.

The aim of the study. Some of these finds, mainly treasures, have been the subject of the specialized research or have been the part of various numismatic publications, which cannot be said of isolated finds that have only been partially 
covered in the scientific literature. At the same time, the individual finds are not inferior to informative treasures, allowing a reconstructing the monetary circulation of a single settlement or city, its economic potential, interregional trade relations and many other aspects that contribute together to the restoration of the historical past. Over the last 10-15 years, the authors of this article have been systematically collecting information about the medieval coins found in Ukraine, some of which have an exact location. Thus, the purpose of this article is the gradual introduction into scientific circulation of the numismatic material originating from the territory of modern Ukraine with its full description, illustrations and outlines, references to current works and catalogues. It opens a series of articles on issues of the XV and XVII centuries, namely the Moldavian coins of Alexander I the Good, Stephen III the Great and one piece of the crown solidus of Sigismund III, found with them. Within the 22 coins described in the article, about 10 were found: 6 coins originate from Chernivtsi region, 1 piece of Moldovan coins were founded in Vinnytsia, Poltava, Volyn and Lviv regions. Other coins were also found on the territory of modern Ukraine, the authors do not know the exact places of their discovery. The Conclusions. The topographic distribution of the finds indicates that the main zone of concentration of Moldavian coins falls on the Chernivtsi region, which is quite natural, given that these lands, mentioned in written sources under the name of Shipinska land (terra Sepenicensis), were was included the part of the Moldavian principality since the end of XIV century. The distribution of Moldovan coin finds in Ukraine corresponds to the same international trade routes that connected Central Europe with the Crimean Peninsula, passing through the territory of modern Ukraine and Moldova, known as "Tatar» and «Moldovan» trade routes; and the mediating the role played by the lands of the Principality of Moldavia in this trade.

Keywords: Moldavian principality, Shipina land, numismatics, single finds, topography of finds, trade routes.

\section{Анотація.}

Протягом минулих двох десятиліть унаслідок розвитку приватного пошуку із застосуванням спеціальної техніки кількість відомих історичних цุінностей різко зросла, щзо відкрило нові можливості для дослідників. Постановка проблеми. Деякі з таких знахідок, в основному скарби, ставали предметом спеціалізованих досліджень або різноманітних нумізматичних праџь, чого не можна сказати про поодинокі знахідки, які лише частково були висвітлені в науковій літературі. При цьому поодинокі знахідки не поступаються інформативністю скарбам, дозволяючи реконструювати монетний обіг окремо взятого поселення або міста, його економічний потенціал, міжрегіональні торговельні зв'язки та багато інших аспектів, які в сукупності сприяють відновленню історичного минулого. Протягом останніх 
10 - 15 років авторами ичієі статті планомірно збиралася інформація про середньовічні монети, знайдені на території Украӥни, деякі з яких мають точне місие виявлення. Таким чином, мета иієї статті полягає в поетапному введенні в науковий обіг нумізматичного матеріалу, щуо походить з території сучасної України, з повноцінним описом, ілюстраціями та контурними абрисами, посиланнями на актуальні роботи та каталоги. Відкриває серію стаття, присвячена емісіям XV і XVII століть, а саме молдавським монетам Олександра I Доброго, Стефана III Великого та одному екземплярові коронного соліду Сигізмунда III, знайденого спільно із зазначенми. Із 22 описаних у статті монет щуодо 10 вдалося зафіксувати місце знахідки: 6 монет походять з Чернівецької області, по 1 екземплярові молдавських монет було зафіксовано у Вінницькій, Полтавській, Волинській та Львівській областях. Інші монети також були виявлені на території сучасної України, про точніші місия їх виявлення авторам не відомо. Висновки. Топографічний розподіл знахідок вказує на те, щуо основна зона концентрації молдавських монет припадає на Чернівещььку область, щуо цілком закономірно, якщу врахувати те, щзо ці землі, згадані в писемних джерелах під назвою Шипинської землі (terra Sepenicensis), входили до складу Молдавського князівства ще $з$ кіния XIV століття. Розподіл знахідок молдавських монет в Украӥні відповідає тим самим міжнародним торговим шляхам, які пов'язували центральну Європу з Кримським півостровом, проходячи територією сучасної України та Молдови, відомі як «татарський» та «молдавський» торгові иляхи; $і$ тієї посередницької ролі, яку відігравали землі Молдавського князівства у цій торгівлі.

Ключові слова: Молдавське князівство, Шипинська земля, нумізматика, одиничні знахідки, топографія знахідок, торгівельні иляхи.

Постановка проблеми. 3 початком «епохи» металодетекторства обсяги нумізматичних матеріалів, що стали знахідками, і не тільки їх, збільшилися настільки значно, що реальні цифри виявлених комплексів та одиничних знахідок ми навряд чи зможемо коли-небудь підрахувати. Деякі з цих знахідок, в основному скарби, ставали предметом спеціалізованих досліджень або входили до складу різноманітних нумізматичних зведень. Це цілком зрозуміло 3 урахуванням їхньої унікальності та важливості для відтворення грошового обігу того чи іншого періоду. На жаль, набагато менше уваги приділялося знахідкам одиничних монет, віднайдених як у поселеннях, так і розрізнено, що також знаходить своє пояснення. Хоча за інформативністю остання категорія ані трохи не поступається першій. Більше того, найчастіше вона дозволяє реконструювати грошовий обіг окремо взятого поселення або міста, його економічний потенціал, міжрегіональні торговельні зв'язки та багато інших аспектів, які сприяють відновленню історичного минулого. 
Враховуючи вище перелічені факти а також те, що протягом останніх 10 - 15 років авторами цієї статті планомірно збиралася інформація про середньовічні монети, знайдені на території України (деякі з них мають точне місце виявлення), ми вирішили поетапно вводити накопичений матеріал до наукового обігу. Спочатку основний акцент ставився на середньовічні монети молдавського походження, що було предметом інтересу одного з авторів, але в ході дослідження 3'ясувалося, що деякі знахідки були виявлені спільно 3 монетами, карбованими в інших країнах.

Таким чином, ми вирішили не обмежуватися лише молдавським матеріалом та публікувати всі середньовічні нумізматичні знахідки, інформацію про які нам удалося зібрати. Ми не ставимо за мету встановлення їхнього ступеня рідкісності для грошового обігу того чи іншого регіону. Основне завдання статей цього типу полягає у введенні нумізматичного матеріалу в науковий обіг, по можливості з повноцінним описом кожної монети, посиланням на найбільш актуальні роботи та каталоги, з якісними ілюстраціями а також історичною довідкою про події, які якимось чином могли вплинути на їхнє поширення.

Викладення основних матеріалів дослідження. Серію статей відкриває добірка з 22 екземплярів монет, викарбуваних у першій половині XV століття (каталог, № $1-20$ ), також дві монети випущені в кінці XV і на початку XVII ст. ${ }^{1}$ (відповідно каталог, № 21 і 22). Оскільки більшість описуваних монет складають досить компактну групу, в каталозі вони наведені, виходячи не 3 місця виявлення, а в їх хронологічному порядку, за країнами, емітентами та періодами/роками випуску. Вказівки місця виявлення наводяться в описові для кожної монети окремо.

Основна група знахідок пов'язана з ім'ям Олександра Доброго (каталог, № 1-20). Його тривале правління характеризується не лише зміцненням центральної влади та численними політичними перетвореннями у країні, а й випуском великого обсягу різноманітної монетної продукції. Молдавська монетно-вагова система, основу якої складає грош, карбований за зразком галицьких грошиків при Людовику I Анжу² (1379 - 1382 рр.) ще при Петрі I Мушаті $^{3}$ (близько 1375 - 1391/1392 рр.), зазнає багаторазових змін, що пов'язані 3 його поетапним та планомірним коригуванням за рахунок уведення багатьох варіацій основного номіналу.

\footnotetext{
${ }^{1}$ Інформація про деякі з цих знахідок була надана на Нумізматичному Конгресі "Moneda uneşte naţiunile”, що проводився у Брашові в 2012 році, та опублікована як короткі тези: Dergaciova L., Bojko-Gagarin A. New findings of Moldavian coins of $14^{\text {th }}-16^{\text {th }}$ centuries in Central and Western Ukraine. A few remarks on the "Moldavian trade route". Primul Congres Internaţional de Numismatică din România. "Moneda uneşte naţiunile". Rezumatele comunicărilor. Braşov, 2012. P. 34-36.

${ }^{2}$ Крижанівський 2007: 74-81, 186-187.

3 Дергачева 2019: 108-120, і особливо 119-120.
} 
Так, крім грошей випускаються монети в півтора гроша, названі в застарілій нумізматичній літературі подвійними грошами ${ }^{1}$, i півгроші. Крім них можуть бути згадані і два інших анепіграфних номінали, які до недавнього часу так само зараховувалися до категорії півгрошів. Це так звані молдавські пули, викарбувані з міді за зразком татарських пулів кінця XIV століття ${ }^{2}$, і дрібні монети, умовно названі півгрошами із заниженою вагою ${ }^{3}$.

Із хронологічно-типологічної точки зору в нумізматичній літературі прийнята типологія, запропонована О. Ілієску у 1970 році ${ }^{4}$ і покладена в основу нумізматичного каталогу «Румунські монети та банкноти» 1977 року5 $^{5}$ Відповідно до іконографічних особливостей монет, що простежуються за збереженими державними печатками та їх відбитками, а також різними геральдичними знаками, присутніми на монетах, О. Ілієску встановив, що існувало шість основних типів або емісійних серій 6 , які були умовно поділені ним на три основні фази у пізнішій роботі теоретичного плану 2000 року ${ }^{7} \mathrm{He}$ будемо їх усіх перераховувати. Зупинимося тільки на тих, до яких відносяться монети з нашого каталогу.

До першої фази монетної продукції Олександра (1400 - 1408 рр.) можуть бути віднесені дореформені гроші І-го типу, карбовані 3 мідного сплаву зі слідами посріблення в перші два роки його правління (№ 1-4), i післяреформений півгрош, викарбуваний 3 досить якісного срібла, найімовірніше близько 1407 - 1408 рр., у ту пору, коли, очевидно, й було проведено саму реформу (№ 5). Після перетворень у монетному виробництві продукція носить регулярний характер, а монетні типи набувають відмінних знаків, які дозволяють відстежувати якість викарбуваної монети перед іï введенням у грошовий обіг. До другої фази (1408 - 1409 рр.) ми можемо віднести лише монету у півтора гроші, випущену з високоякісного срібла, 3 новим типом легенди та шоломом, розташованим над щитом реверсу (№ 6). Третя фаза монетної продукції Олександра представлена в нашому каталозі різними номіналами III-го, IV-го і V-го типів, що хронологічно вписуються в період 1409 - 1431 рр. Це екземпляр у півтора гроша III-го типу, відзначений трояндою над щитом реверсу (№ 7), монети у півтора гроша та півгроші IV-го типу, з головою бика над щитом реверсу (відповідно, № 8-10 та 11-12), та мідні пули, віднесені до V типу, з буквою «А» праворуч від щита реверсу (№ 15-17). До цієї ж фази можуть бути віднесені ще два півгроші, що залишалися донедавна поза типологією, запропонованою О. Ілієску. Їхня відмінність - буква «Р», розташована над щитом реверсу в перевернутій позиції (№ 12-13). Іконографічні

\footnotetext{
1 Див.: Iliescu 2000: 65-69 та список літератури з даної проблеми.

${ }^{2}$ Dergaciova 2013-2014: 154-157.

${ }^{3}$ Dergaciova 2012: 65-68.

${ }^{4}$ Iliescu 1970: 26-28.

${ }^{5}$ Buzdugan, Luchian, Oprescu 1977: 58-64.

${ }^{6}$ Iliescu O. Moneda ... P. 26-28.

${ }^{7}$ Iliescu O. Aspecte ale economiei ... P. 79-83.
} 
особливості екземплярів цього типу, які добре простежуються за формою лілій, розташованих у двох вертикальних рядах у другому полі щита реверсу (їх число - 6 одиниць), як і використання тієї ж перевернутої літери «Р» зліва від щита реверсу, дозволяє співвіднести їх випуск із півторагрошами IV-го типу (порівняти з № 12-13 і № 9) і датувати тим самим періодом, що вписується в період 1415 - 1425 pp.

Найцікавішими, з економічної точки зору, стали дві монети невеликого діаметру (№ 19-20). Виходячи із зображень, що збереглися на обох сторонах, вони можуть бути віднесені до І-го типу і становити обрізані гроші (порівняти 3 № 19-20 і № 1-4). Екземпляри подібного роду поки що не ставали предметом спеціального дослідження, хоча їхня кількість зростає серед випадкових знахідок, і деякі 3 них уже були введені в науковий обіг ${ }^{1}$. Поки що важко сказати, коли монети цього типу були обрізані. Це могло статися невдовзі після введення грошей I типу у грошовий обіг, тобто після 1402 року, в період, коли монети дрібного номіналу не вироблялися, відповідно, існувала гостра потреба в розмінній монеті. Але тоді виникає питання, на зразок монет якого номіналу обрізалися ці гроші. Або ж у період, коли почали випускатися дрібні фракції гроша (півгроші та півгроші із заниженою вагою), тобто після монетної реформи 1407 - 1408 рр., які могли стати прототипом для подібних екземплярів. Не вдаючись у подробиці цього феномену, який вимагає грунтовного вивчення із залученням великої бази даних, відзначимо, що поки залишається очевидним той факт, що вилучення 3 обігу монет більшого номіналу 3 метою їхнього подальшого обрізання було доцільним для населення і мало досить планомірний характер.

Останні дві монети 3 нашого каталогу належать до молдавської та польської продукції пізнішого періоду. Одна монета - це гріш II типу Стефана III і датується періодом 1476/1479 - 1497 pp. (№ 21); інша монета - це коронний солід Сигізмунда III, викарбуваний у 1624 (№ 22).

Коротко описавши монетну продукцію, розглянемо їхню топографію відповідно до сучасного територіально-адміністративного поділу України. На карті місця виявлення монет відповідають або конкретним населеним пунктам (карта, № 4, 10-11, 18), або ж адміністративним центрам тієї чи іншої області або району (карта, № 1, 3, 5-6, 21-22). Із 22 монет тільки для десяти ми маємо більшменш точну інформацію про місце їх виявлення. Монети походять із таких областей:

○ Чернівецької (6 екз.) - грош І-го типу Олександра, виявлений разом 3 грошем Стефана III та солідом Сигізмунда III у Хотинському районі (№ 1 , 21-22); монета в півтора гроша IV типу Олександра I, знайдена в селі

\footnotetext{
${ }^{1}$ Один екземпляр був знайдений у селі Резень Яловенського району республіки Молдова (Dergaciova L. Monede medievale ... P. 73, nr. 21).
} 
Вітрянка Сокирянського району (№ 10); один півгрош І-го типу і півтора гроша II-го типу Олександра I (№ 5-6);

○ Вінницької (1 екз.) - грош І-го типу Олександра, знайдений у місті Брацлав Немирівського району спільно 3 кількома молдавськими та польськими монетами, про які не збереглося більш детальної інформації (див. інформацію в каталозі для № 4);

○ Полтавської (1 экз.) - грош І-го типу Олександра (№ 3);

○ Львівської (1 екз.) - півгрош IV типу Олександра, виявлений у селі Борщовичі (№ 11);

○ Волинської (1 екз.) - анепіграфна монета Олександра I невстановленого типу, виявлена поблизу міста Любомля (№ 18).

Інші монетні знахідки з нашого каталогу були виявлені на території України. Для них ми не маємо більш точних даних (12 прим.; № 2, 7-9, 12-17, 19-20).

Як бачимо 3 карти, основна зона концентрації молдавських монет припадає на Чернівецьку область, що цілком закономірно, враховуючи, що ці землі, згадані в писемних джерелах під назвою Шипинської землі (terra sepenicensis), входили до складу Молдавського князівства ще 3 кінця XIV століття ${ }^{1}$. Інші знахідки, для яких ми маємо більш-менш достовірну інформацію про місце їх виявлення, розподіляються у двох основних напрямках - у північно-західному та північно-східному. Їхня концентрація відповідає тим самим міжнародним торговим шляхам, які пов’язували центральну Свропу з Кримським півостровом, проходячи територією сучасних України та Молдови, відомі як «татарський» та «молдавський» торгові шляхи; i тієї посередницької ролі, яку відігравали землі Молдавського князівства у цій торгівлі.

Висновки дослідження. Враховуючи невеликий обсяг даних, який ми вводимо в науковий обіг, як і інформацію, яку ще потрібно опублікувати, поки що рано робити конкретні висновки про грошовий обіг молдавської монети на території сучасної України. Зазначимо лише, що монетні знахідки, що публікуються в цій статті, доповнюють уже відомі дані, зібрані для ПівденноЗахідної та Західної частини України та зазначені в роботах О. Огуя², C. Пивоварова ${ }^{3}$, С. Пивоварова, Н. Боднарюка та Л. Дергачової4 А. Крижанівського ${ }^{5}$ та інших.

\footnotetext{
1 Дивись дискусії з цієї теми у таких роботах: Panaitescu 1956: 103; Purici 1996: 349-362; Балух 2008: 150 157; Балух 2010: 27-39; Pînzar 2016.

2 Огуй 1997; Огуй 2008; Огуй 2009.

3 Пивоваров 2002; Пивоваров 2003: 171-182; Пивоваров 2009: 21-35 тощо.

${ }^{4}$ Bodnariuc, Dergaciova, Mordovin 2019: 111-138, дивись і список літератури.

${ }^{5}$ Kryżaniwskij 2009: 171.
} 


$$
\begin{gathered}
\text { Каталог }^{1} \\
\text { Молдавія } \\
\text { Олександр I Добрий }(1400-1432 \text { рр.) } \\
\text { Грош }(1400-1402 \text { pp. })
\end{gathered}
$$

Аверс. Голова бика анфас, зірка між рогами, троянда праворуч, півмісяць ліворуч від голови бика; крапковий обідок. Кругова легенда у зовнішньому крапковому обідку.

Реверс. Розсічений геральдичний щит: I - три балки, II - дві лілії, розташовані вертикально $1 / 1$; крапковий обідок. Кругова легенда у зовнішньому крапковому обідку.

Iliescu O. Moneda ... P. 27, серія I (1400 - 1408 pp.); Buzdugan G., Luchian O., Oprescu C. Monede și bancnote ... Nr. 361-367, тип Id; Iliescu O. Aspecte ale economiei ... P. 79, nr. 2, фаза I (1400 - 1408 pp.), емісія I (1400 - 1408 pp.); Pârvan K. Monede moldovenești descoperite în Dobrogea. Istro-Pontica. Muzeul tulcean la a 50-a aniversare, 1950 - 2000 pp. Omagiu lui Simion Gavrilă la 45 de ani de activitate, 1955 - 2000. Tulcea, 2000. P. 563-572 (1399/1400 - 1402 pp.).

1. $\mathrm{AE}, 0,7$ гр, 18,5 мм; обламана, радіальні тріщини, більша частина зображення аверсу та реверсу непомітна.

Аверс: ...SALE...

Реверс: ...DE...

Знайдена у Хотинському районі Чернівецької області, 2010/2011, разом 3 монетами 21-22 з цього каталогу.

2. АЕ з незначними слідами посріблення, 0,6 гр, 18 мм; дрібні обломи на краю монети, численні радіальні тріщини.

Аверс: ...XANDD(D перегорнута)RVS

Реверс: ...LDAVIDNS...

Знайдено в Україні, 2010.

3. АЕ, 0,50 гр, 18 мм, $11 \mathrm{~h}$; радіальні тріщини, сильно кородована, більшість зображення аверсу і реверсу невидима.

Аверс: .... S...

Реверс: ...Про...

Знайдена у Полтавській області, 2011.

\footnotetext{
${ }^{1}$ Опис монет подано за геральдичними канонами, де справа знаходиться ліворуч від того, що дивиться, а ліворуч, відповідно, праворуч від того, що дивиться.
} 
Аверс. Голова бика в анфас, зірка між рогами, півмісяць праворуч, троянда ліворуч від голови бика; крапковий обідок. Кругова легенда у зовнішньому крапковому обідку.

Реверс. Розсічений геральдичний щит: I - три балки, II - дві лілії, розташовані вертикально 1/1; крапковий обідок. Кругова легенда у зовнішньому крапковому обідку.

Iliescu O. Moneda ... P. 27, серія I (1400 - 1408 pp.); Buzdugan G., Luchian O., Oprescu C. Monede și bancnote ... Nr. 359-360, тип Ic; Iliescu O. Aspecte ale economiei ... P. 79, nr. 2, фаза I (1400 - 1408 рр.), емісія I (1400-1408); Pârvan K. Monede moldovenești descoperite în Dobrogea. Istro-Pontica. Muzeul tulcean la a 50-a aniversare, 1950 - 2000. Omagiu lui Simion Gavrilă la 45 de ani de activitate, 1955 - 2000 pp. Tulcea, 2000. P. 563-572 (1399/1400 - 1402 pp.).

4. АЕ, ? гр, 16 мм; сліди корозії не дозволяють відновити більшу частину зображення аверсу та реверсу.

Аверс: ... XAN...

Реверс: ... VID(D перегорнута)N...

Знайдено у місті Брацлав Немирівського району Вінницької області, 2011. За словами знахідника, спільно 3 кількома молдавськими монетами, а саме грошами Стефана (можливо III, приписка авторів) та півгрошем Олександра I, a також одним польським півгрошем 1548 року Сигізмунда II Августа серед мідних уламків.

http://forum.violity.kiev.ua/viewtopic.php?p=4263948\#4263948 (переглянуто 22.01.2011, цей екземпляр).

\section{Півгрош (близько 1407 - 1408 рр.)}

Аверс. Голова бика в анфас, зірка між рогами, троянда праворуч, лілія на сліблі затиснених у роті бика, над якою розташований півмісяць ліворуч від голови бика; крапковий обідок.

Реверс. Розсічений геральдичний щит: I - три балки, II - дві лілії, розташовані вертикально $1 / 1$, по одній лілії зверху, праворуч та ліворуч від щита; крапковий обідок.

Iliescu O. Moneda ... P. 27 серія I (1400 - 1408 pp.); Buzdugan G., Luchian O., Oprescu C. Monede și bancnote ... Nr. 368-370, тип I; Iliescu O. Aspecte ale economiei ... P. 79, nr. 2, фаза I (1400 - 1408 рр.), емісія I (1400 - 1408 рр.); Дергачева Л. В. Клад молдавских монет из села Кочулия и молдавско-польские отношения начала XV в. Средневековая Нумизматика Восточной Европы. Выпуск 6. Москва, 2017. С. 221-222 с предложением даты выпуска монет этого типа и номинала в интервале 1407 - 1408 гг.

5. AR, ? гр, близько 15 мм.

Знайдено у Чернівецькій області, 2011. 


$$
\text { Півтора гроша }(1408-1409 \text { рр.) }
$$

Аверс. Голова бика в анфас, зірка між рогами, троянда праворуч, півмісяць ліворуч від голови бика; крапковий обідок. Кругова легенда у зовнішньому крапковому обідку.

Реверс. Розсічений геральдичний щит: I - три балки, II - сім лілій, розташованих у двох вертикальних рядах 4/3, шолом над щитом; крапковий обідок. Кругова легенда у зовнішньому крапковому обідку.

Iliescu O. Moneda ... Р. 27, подвійний грош, серія II (1408); Buzdugan G., Luchian O., Oprescu C. Monede și bancnote ... Nr. 371, подвійний грош, тип II; Iliescu O. Aspecte ale economiei ... P. 80, nr. 5, півтора гроша, фаза II (1408 - 1409 pp.), емісія III (1408 - 1409 рр.); Дергачева Л. В. Клад молдавских монет из села Кочулия и молдавско-польские отношения начала XV в. Средневековая Нумизматика Восточной Европы. Выпуск 6. Москва, 2017. С. 221-222 с предложением даты выпуска монет этого типа в период 1408 - 1409 гг.

6. AR, ? гр, близько 22 мм.

Aверс: +MONE•ALEXANDRV

Реверс: +WD•MOLDAVIENSS

Знайдена в Чернівецькій області, 2011.

Півтора гроша (близько 1409 - 1415 рр.)

Аверс. Голова бика в анфас, зірка між рогами, троянда праворуч, півмісяць ліворуч від голови бика; крапковий обідок. Кругова легенда у зовнішньому крапковому обідку.

Реверс. Розсічений геральдичний щит: I - три балки, II - сім лілій, розташованих у двох вертикальних рядах 4/3, троянда над щитом; крапковий обідок. Кругова легенда у зовнішньому крапковому обідку.

Iliescu O. Moneda ... Р. 27, подвійний гріш, серія III (1408); Buzdugan G., Luchian O., Oprescu C. Monede și bancnote ... Nr. 377-380, подвійний гріш, тип III; Iliescu O. Aspecte ale economiei ... P. 80, nr. 7, півтора гроша, фаза III (1409 - 1431 pp.), емісія IV (1409-1415 рр.).

7. AR, 1,1 гр, 22х17 мм; фрагментована, зі слідами корозії, які не дозволяють відновити більшу частину зображення аверсу та реверсу.

Аверс: ...A...NDRI

Реверс: +WDM...

Знайдено в Україні, 2010. 
Півтора гроша (близько 1415 - 1425 рр.)

Аверс. Голова бика в анфас, зірка між рогами, троянда праворуч, півмісяць ліворуч від голови бика; крапковий обідок. Кругова легенда у зовнішньому крапковому обідку.

Реверс. Розсічений геральдичний щит: I - три балки, II - шість лілій, розташованих у двох вертикальних рядах $3 / 3$, голова бика над щитом та частково його перекриває, ключ праворуч від щита; крапковий обідок. Кругова легенда у зовнішньому крапковому обідку.

Iliescu O. Moneda ... Р. 28, подвійний гріш, серія IV (1415 - 1430 рр.); Buzdugan G., Luchian O., Oprescu C. Monede şi bancnote ... Nr. 399, подвійний гріш, тип IV; Iliescu O. Aspecte ale economiei ... Р. 80, nr. 10, півтора гроша, фаза III (1409 - 1431 рр.), емісія V (1415 - 1425 рр.).

8. AR, 1,01 гр, 20 мм.

Аверс: +MONE:ALEXANDRI

Pеверс: +WD:MOLDAVIENSIS

Знайдена в Україні, 2010.

http://forum.violity.kiev.ua/viewtopic.php?t=293536 (переглянуто 24.11.2010, цей екземпляр).

Аверс. Голова бика в анфас, зірка між рогами, троянда праворуч, півмісяць ліворуч від голови бика; крапковий обідок. Кругова легенда у зовнішньому крапковому обідку.

Реверс. Розсічений геральдичний щит: I - три балки, II - шість лілій, розташованих у двох вертикальних рядах $3 / 3$, голова бика над щитом і частково його перекриває, літера Р у перевернутому положенні зліва від щита; крапковий обідок. Кругова легенда у зовнішньому крапковому обідку.

Iliescu O. Moneda ... Р. 28, подвійний грош, серія IV (1415 - 1430 pp.); Buzdugan G., Luchian O., Oprescu C. Monede și bancnote ... Nr. 398, подвійний грош, тип III; Iliescu O. Aspecte ale economiei ... P. 80, nr. 10, півтора гроша, фаза III (1409 - 1431 рр.), емісія V (1415 - 1425 рр.).

9. $\mathrm{AR}, 1,25$ гр, 22 мм; частково відсутнє зображення на обох сторонах монети.

Аверс: ....NEALE...DRI

Pеверс: +WDM...AVIENSIS

Знайдено в Україні, 2010. 
Аверс. Голова бика в анфас, зірка між рогами, троянда(?) праворуч, півмісяць ліворуч від голови бика; крапковий обідок. Кругова легенда у зовнішньому крапковому обідку.

Реверс. Розсічений геральдичний щит: I - три балки, II - шість лілій, розташованих у двох вертикальних рядах $3 / 3$, голова бика над щитом та частково його перекриває, півмісяць ліворуч від щита; крапковий обідок. Кругова легенда у зовнішньому крапковому обідку.

Iliescu O. Moneda ... Р. 28, подвійний гріш, серія IV (1415 - 1430 pp.); Buzdugan G., Luchian O., Oprescu C. Monede şi bancnote ... Nr. 407, подвійний гріш, тип III; Iliescu O. Aspecte ale economiei ... P. 80, nr. 10, півтора гроша, фаза III (1409 - 1431 рр.), емісія V (1415 - 1425 рp.).

10. AR, ? гр, близько 21 мм; сильне зміщення штемпеля аверса, частково відсутнє зображення з обох боків монети.

Аверс: + ... ONEALEX ... I

Реверс: +WDMOLDAVIEN...IS

Знайдено у селі Вітрянка Сокирянського району Чернівецької області, 2011.

$$
\text { Півгрош (близько } 1415 \text { - } 1425 \text { рр.) }
$$

Аверс. Голова бика в анфас, зірка між рогами, троянда праворуч, півмісяць ліворуч від голови бика; крапковий обідок.

Реверс. Розсічений геральдичний щит: I - три балки, II - п’ять лілій, розташованих у трьох горизонтальних рядах 2/2/1, голова бика над щитом i частково його перекриває, троянда праворуч, півмісяць ліворуч від неї, літера I ліворуч від щита; крапковий обідок.

Iliescu O. Moneda ... P. 28, серія IV (1415 - 1430 pp.); Buzdugan G., Luchian O., Oprescu C. Monede și bancnote ... Nr. 412, тип IV; Iliescu O. Aspecte ale economiei ... P. 81, nr. 12, фаза III (1409 - 1431 pp.), емісія V (1415 - 1425 рр.).

11. AR, 0,5 гр, 15 мм; незначний зсув штемпеля реверсу. Знайдено у селі Борщовичі Львівської області, 2011.

http://forum.violity.kiev.ua/viewtopic.php?t=666784 (переглянуто 22.01.2012, цей екземпляр).

Аверс. Голова бика в анфас, зірка між рогами, троянда праворуч, півмісяць зліва голови бика; крапковий обідок.

Реверс. Розсічений геральдичний щит: I - три балки, II - п’ять лілій, розташованих у трьох горизонтальних рядах 2/2/1, голова бика над щитом i 
частково його перекриває, троянда праворуч, півмісяць зліва від неї; крапковий обідок.

Iliescu O. Moneda ... P. 28, серія IV (1415 - 1430 pp.); Buzdugan G., Luchian O., Oprescu C. Monede și bancnote ... Nr. 410 - 411, тип IV; Iliescu O. Aspecte, ale economiei ... P. 81, nr. 12, фаза III (1409 - 1431 pp.), емісія V (1415 1425 pp.).

12. $\mathrm{AR}, 0,19$ гр, $13 \times 12$ мм; обламана, частково відсутнє зображення на обох сторонах монети.

Знайдено в Україні, 2010.

$$
\text { Півгрош (близько } 1409 \text { - } 1425 \text { рр.) }
$$

Аверс. Голова бика в анфас, зірка між рогами, троянда праворуч, півмісяць зліва голови бика; крапковий обідок.

Реверс. Розсічений геральдичний щит: I - три балки, II - шість лілій, розташованих у двох вертикальних рядах 3/3, літера $\mathrm{P}$ у перевернутому положенні над щитом та частково його перекриває, троянда праворуч від щита; крапковий обідок.

Buzdugan, Luchian, Oprescu 1977, nr. -; порівняти nr. 385, тип III та nr. 430, тип V; Дергазіова Л. Монеде medievale descoperite la Răzeni (II). Contribuții la tipologia emisiunilor moldovenești. Studii și cercetări de numismatică. Serie Nouă. Vol. V-VIII (XVII-XX), 2014 - 2017 pp. București, 2018. P. 97-99 з дискусією про атрибуцію монет цього типу та їх можливим датуванням (1409-1425 pp.).

13. АЕ, 0,32 гр, 13 мм; частково відсутнє зображення на обох сторонах монети.

Знайдено в Україні, 2010.

http://forum.violity.kiev.ua/download.php?id=70776 (переглянуто 09.01.2010, цей екземпляр).

14. АЕ, ? гр, 13 мм.

Знайдено в Україні, 2010/2011.

$$
\text { Пул (близько } 1425 \text { - } 1430 \text { рр.) }
$$

Аверс. Голова бика в анфас, зірка між рогами, троянда праворуч, півмісяць ліворуч від голови бика; крапковий обідок.

Реверс. Розсічений геральдичний щит: I - три балки, II - сім лілій, розташованих у двох вертикальних рядах 4/3, літера А праворуч від щита; крапковий обідок. 
Iliescu O. Moneda ... P. 28, півгріш, серія V (1430); Buzdugan G., Luchian O., Oprescu C. Monede și bancnote ... Nr. 418, півгріш, тип V; Iliescu O. Aspecte, ale economiei ... P. 82, nr. 21, півгріш, фаза III, емісія IX (1425 - 1430 pp.); Dergaciova L. New Coin Hoard finds ... P. 154-157 термін пул для даної категорії монет.

15. АЕ, 0,55 гр, 14 мм.

Знайдено в Україні, 2010.

16. $\mathrm{AE}, 0,39$ гр, 15 мм, обламана.

Знайдено в Україні, 2010.

17. AЕ, 0,19 гр, 15 мм; частково відсутнє зображення на обох сторонах монети; численні радіальні тріщини.

Знайдено в Україні, 2010.

Анепіграфна монета не встановленого типу (близько 1409 - 1430 рр.)

Аверс. Голова бика в анфас, зірка між рогами, троянда праворуч, півмісяць зліва голови бика; крапковий обідок.

Реверс: слабко помітні сліди горизонтальних балок та лілій.

Buzdugan, Luchian, Oprescu 1977, nr. -; порівняти nr. 418 - 461.

18. $\mathrm{AE}$ ? гр, 13 мм; слабко помітне зображення реверсу, яке дозволяє встановити всі його компоненти.

Знайдено поблизу міста Любомля Волинської області, 2010 року.

$$
\text { Гроші (1400 - } 1402 \text { рр.) обрізані }
$$

Аверс. Голова бика в анфас, зірка між рогами, троянда праворуч, невстановлений елемент зліва голови бика; крапковий обідок. Кругова легенда у зовнішньому крапковому обідку.

Реверс. Розсічений геральдичний щит: I - три балки, II - дві лілії, розташовані вертикально $1 / 1$; крапковий обідок. Кругова легенда у зовнішньому крапковому обідку.

Для необрізаних (цілих) екземплярів дивись: Iliescu O. Moneda ... P. 27, тип I (1400 - 1408 pp.); Buzdugan G., Luchian O., Oprescu C. Monede și bancnote ... Nr. 361-367, тип Id; Iliescu O. Aspecte, ale economiei ... P. 79, nr. 2, гріш, фаза I (1400 - 1408 рр.), емісія I (1400 - 1408 рр.).

19. $\mathrm{AE}, 0,26$ г, $14 \times 13 \mathrm{~mm}$.

Знайдено в Україні, 2011. 
http://forum.violity.kiev.ua/viewtopic.php?t=671292 (переглянуто 22.01.2011, цей екземпляр).

Аверс. Голова бика в анфас, зірка між рогами, півмісяць праворуч, невстановлений елемент зліва голови бика; крапковий обідок. Кругова легенда у зовнішньому крапковому обідку.

Реверс. Розсічений геральдичний щит: I - три балки, II - дві лілії, розташовані вертикально $1 / 1$; крапковий обідок. Кругова легенда у зовнішньому крапковому обідку.

Для необрізаних (цілих) екземплярів дивись: Iliescu O. Moneda ... P. 27, тип I (1400 - 1408 pp.); Buzdugan G., Luchian O., Oprescu C. Monede și bancnote ... Nr. 359-360, тип Ic; Iliescu O. Aspecte, ale economiei ... P. 79, nr. 2, грош, фаза I (1400 - 1408 рр.), емісія I (1400 - 1408 pp.).

20. АЕ зі слідами посріблення, 0,27 гр, 10x9 мм.

Знайдено в Україні, 2010/2011.

$$
\begin{gathered}
\text { Стефан III Великий (1457 - } 1504 \text { рр.) } \\
\text { Грош (1476/1479 - } 1497 \text { рр.) }
\end{gathered}
$$

Аверс. Голова бика в анфас, троянда між рогами, троянда праворуч, півмісяць зліва від голови бика; крапковий обідок. Кругова легенда у зовнішньому крапковому обідку.

Реверс. Подвійний рівносторонній хрест у геральдичному щиті; крапковий обідок. Кругова легенда у зовнішньому крапковому обідку.

Iliescu O. Moneda ... P. 33, тип II (1480 - 1504 pp.); Buzdugan G., Luchian O., Oprescu C. Monede și bancnote ... Nr. 637, тип II, але троянда 1; OberländerTârnoveanu E. Emisiunile monetare bătute pe teritoriul Moldovei în vremea lui Ștefan cel Mare (1457 - 1504 pp.). Analiză critică. Cercetări Numismatice. Vol. IX-XI. București, 2005. Р. 303, тип II, варіант 1, підваріант b (1476/1479 - 1497 pp.).

21. AR, 0,6-0,7 гр, 15 мм.

Aверс: +MONETAMOLDAVI

Pеверс: +STEFANVSVOIEV

Знайдено у Хотинському районі Чернівецької області, 2010/2011, разом 3 монетами 1 та 22 з цього каталогу. 


\section{Річ Посполита (Польсько-Литовська унія) \\ Сигізмунд III (1587 - 1632 рр.) \\ Коронний солід 1624 року}

Аверс. Під короною монограма $\mathrm{S}$ із гербом Ваза посередині; лінійний обідок. Кругова легенда у зовнішньому лінійному обідку.

Реверс. Під короною герби Польщі та Литви у здвоєних медальйонах, династична емблема Ваза у геральдичному щиті під медальйонами; крапковий обідок. Кругова легенда у зовнішньому крапковому обідку.

Kamiński C., Kurpiewski J. Katalog monet polskich 1587 - 1632 (Zyrmunt III Waza). Warszawa: Krajowa agencja wydawnicza, 1990, nr. 230-231, коронний солід 1624.

22. AR, ? гр, близько 20 мм; обламана по краю.

Аверс: SIG3D:G: - R PO M D L.

Реверс: SOLID R - POL1624.

Знайдено у Хотинському районі Чернівецької області, 2010/2011, разом 3 монетами 1 та 21 з цього каталогу.

\section{References}

Baluh, O. (2008) Perehid «Shypyns'koi' zemli» pid vladu moldavs'kyh vojevod u drugij polovyni $70 h-90 h r$. XIV st. [The transitiona of "Shipina land" under the rule of Moldovan voievodes in the second half of $70 \mathrm{~s}-90 \mathrm{~s}$ of the $14^{\text {th }} \mathrm{c}$.]. Bukovyns'kyj zhurnal. 2. 150-157. [in Ukrainian].

Baluh, A.V. (2010) «Shypynskaja zemlja»: ystoky y sud'ba ["Shipina Land": origins and destiny]. Stratum plus. 6. 27-39. [in Russian].

Dergacheva, L.V. (2017) Klad moldavskyh monet yz sela Kochulyja y moldavskopol'skye otnoshenyja nachala XV v. [The coin hoard of Moldovan coins found in the Cociulia village and Moldovan-Polish relations at the beginning of the $15^{\text {th }}$ c.]. Srednevekovaja Numizmatika Vostochnoj Evropy. 6. 213-235. [in Russian].

Dergacheva, L.V. (2019) Gosudarstvennaja i dinasticheskaja jemblemy na pervyh moldavskih jemissijah XIV veka ( $k$ voprosu o tom, chto schitat' aversom, a chto reversom monet Petra I) [State and Dynastic Emblems on the first Moldovan issues of the $14^{\text {th }}$ century (to the problem of what is to consider an obverse and what is the reverse of Peter's coins)]. Visnyk L'vivs'kogo universytetu. Serija istorychna. Specvypusk. 108-122. [in Russian].

Kryzhanivs'kyj A. (2007) L'vivs'kyj monetnyj dvir u XIV-XV stolittjah [Lviv Mint in the $14^{\text {th }}-15^{\text {th }}$ centuries]. L'viv: VAT L'vivoblenergo. [in Ukrainian].

Oguj O.D. (1997) Monetno-lichyl'ni najmenuvannja na Bukovyni ta v Moldovi (kinec' 14 - persha tretyna 19 st.): problema funkcional'nyh polinominacij $v$ 
adaptyvnyh terminosystemah [Coin-counting names in Bukovina and Moldova (end of the $14^{\text {th }}$ - first third of the $19^{\text {th }} \mathrm{c}$.): to the problem of functional polynomials in adaptive terminologies]. Chernivci: Ruta. [in Ukrainian].

Oguj O.D. (2008) Monetni znahidki na Bukovyni. Systemno-kvantytatyvne zistavlennja [Coin finds in Bukovina. System-quantitative comparison]. Chernivci: Ruta. [in Ukrainian].

Oguj O.D. (2009) Istorija obigu groshovyh odynyc' ta i'h najmenuvan' na Bukovyni. Chastyna 1 (1370-1475) [History of monetary circulation and their denominations in Bukovina. Part 1 (1370-1475)]. Chernivci: Chernivec'kyj Nacional'nyj Universytet. [in Ukrainian].

Pyvovarov S. (2002) Numyzmatychni pam'jatky Bukovyny (antychnyj ta seredn'ovichnyj chas) [Numismatic monuments of Bukovina (ancient and medieval times)]. Chernivci: «Zelena Bukovyna». [in Ukrainian].

Pyvovarov S. (2003) Seredn'ovichni numizmatychni materialy $v$ arheologichnyh kompleksah Bukovyny [Medieval numismatic materials in the archaeological complexes of Bukovina]. Naukovyj visnyk Chernivec'kogo Universytetu. Istorija. Politychni nauky. Mizhnarodni vidnosyny. Zbirnyk naukovyh prac'. 173-174. Chernivci: Ruta. 171-182. [in Ukrainian].

Pyvovarov S. (2009) Moldavs'ki monety na terytorii' Bukovyny (znahidky na arheologichnyh pam'jatkah) [Moldovan coins on the territory of Bukovina (finds at archeological sites)]. Pytannja starodavn'oi' ta seredn'ovichnoi' ystorii', arheologii' j etnologii' (zbirnyk naukovyh prac'). 2(28). Chernivci: Prut. 21-35. [in Ukrainian].

Bodnariuc, N. \& Dergaciova, L. \& Mordovin, M. (2019) Descoperiri numismatice și arheologice din Nordul Bucovinei (I). [Numismatic and archaeological discoveries from Northern Bukovina] Arheologia Moldovei [The archeology of Moldova]. (42). 111-138. [in Romanian].

Buzdugan, G. \& Luchian, O. \& Oprescu, C. (1977) Monede și bancnote Româneşti. [Coins and banknotes of Romania]. Bucureşti: Sport. [in Romanian].

Dergaciova, L. (2011-2012) Monede medievale descoperite la Rezeni. Contribuții la tipologia emisiunilor moldovenești. [Medieval coins discovered in Rezeni. Contributions to the typology of the Moldovan emissions]. Studii și cercetări de numismatică. Serie Nouă. [Numismatics studies and researches. New Series]. (II (XIV)), 65-79. [in Romanian].

Dergaciova, L. (2013-2014) New Coin Hoard finds of Moldovan divisional specimens. Contributions to the Knowledge of Monetary System of Alexander I (1399/1400-1432). Oltenia. Studii și comunicări. Arheologie-Istorie. [Oltenia. Studies and communications. Archeology History]. (20-21). 154-173. [in English].

Dergaciova, L. (2018) Monede medievale descoperite la Răzeni (II). Contribuții la tipologia emisiunilor moldovenești. [Medieval coins discovered in Rezeni (II). 
Contributions to the typology of the Moldovan emissions]. Studii și cercetări de numismatică. Serie Nouă. [Numismatics studies and researches. New Series]. (V-VIII (XVII-XX)), 97-112. [in Romanian].

Dergaciova, L. \& Bojko-Gagarin, A. (2012) New findings of Moldavian coins of $14^{\text {th }}$ $16^{\text {th }}$ centuries in Central and Western Ukraine. A few remarks on the "Moldavian trade route". Abstracts of papers: Primul Congres Internaţional de Numismatică din România. "Moneda uneşte naţiunile”. [The First International Numismatic Congress in Romania. "Currency unites nations”]. Braşov, pp. 3436. [in English].

Iliescu, O. (1970). Moneda în România (491-1864). [Coins in Romania (491-1864)]. Bucureşti: Meridiane. [in Romanian].

Iliescu, O. (2000). Aspecte ale economiei monetare în Moldova sub domnia lui Alexandru cel Bun. [Aspects of the monetary economy in Moldova under the reign of Alexander the Great]. Revista Istorică. Serie Nouă. [Historical Journal. The New Series]. Vol. XI. (1-2). 59-95. [in Romanian].

Kamiński, C. \& Kurpiewski, J. (1990) Katalog monet polskich 1587-1632 (Zyrmunt III Waza). [The catalogue of the Polish coins 1587-1632. The Sigismund III Wasa]. Warszawa: Krajowa agencja wydawnicza. [in Polish].

Kryżaniwskij, A. (2009). Próba rekonstrukcji nie notowanych skarbów monet XIV-XV wieku znalezionych na Ukraine zachodniej. [An attempt to reconstruct the unlisted treasures of 14th-15th century coins found in western Ukraine]. Biuletyn Numizmatyczny. [Numismatic Bulletin]. (3). 161-180. [in Polish].

Oberländer-Târnoveanu, E. (2005). Emisiunile monetare bătute pe teritoriul Moldovei în vremea lui Ştefan cel Mare (1457-1504). Analiză critică. [Monetary issues on the territory of Moldova during the reign of Stephen the Great (1457-1504). The Critical analysis]. Cercetări Numismatice [Numismatic Research]. (IXXI). 299-388.

Panaitescu, P. P. (1956) Din istoria luptei pentru independența Moldovei în veacul al XIV-lea. Primele lupte pentru independență ale Țărilor Romîne [From the history of the struggle for Moldovan independence in the 14th century. The first struggles for independence of the Romanian Lands]. Studii. Revista de Istorie şi Filosofie. [Studies. The Journal of History and Philosophy]. Vol. IX. (4). 95115. [in Romanian].

Pârvan, K. (2000) Monede moldovenești descoperite în Dobrogea. Istro-Pontica. Muzeul tulcean la a 50-a aniversare, 1950-2000. [Moldovan coins founded in Dobrogea. Istro-Pontica. Tulcea Museum on its 50th anniversary, 1950-2000]. Omagiu lui Simion Gavrilă la 45 de ani de activitate, 1955-2000. [Tribute to Simion Gavrilă at 45 years of activity, 1955-2000]. Tulcea. pp. 563-572. [in Romanian].

Pînzar, A. (2016) Hotarul de nord al Moldovei (de la formare, în secolul al XIV-lea, până la statornicirea lui pe Ceremuș, Colacin și Nistru). [The northern border 
of Moldova (from its formation in the 14th century until its establishment on Ceremuș, Colacin and Nistru)]. Iași: Editura Universității „Alexandru Ioan Cuza". [in Romanian].

Purici, Ș. (1996) Moldova față de Principatul Halici în sec. XII-XIV. [Moldova compared to the Galician Principality in the 15th century XII-XIV]. Analele Bucovinei. [Annals of Bukovina]. Vol. III. (2). 349-362. [in Romanian].

\section{Ілюстрації}

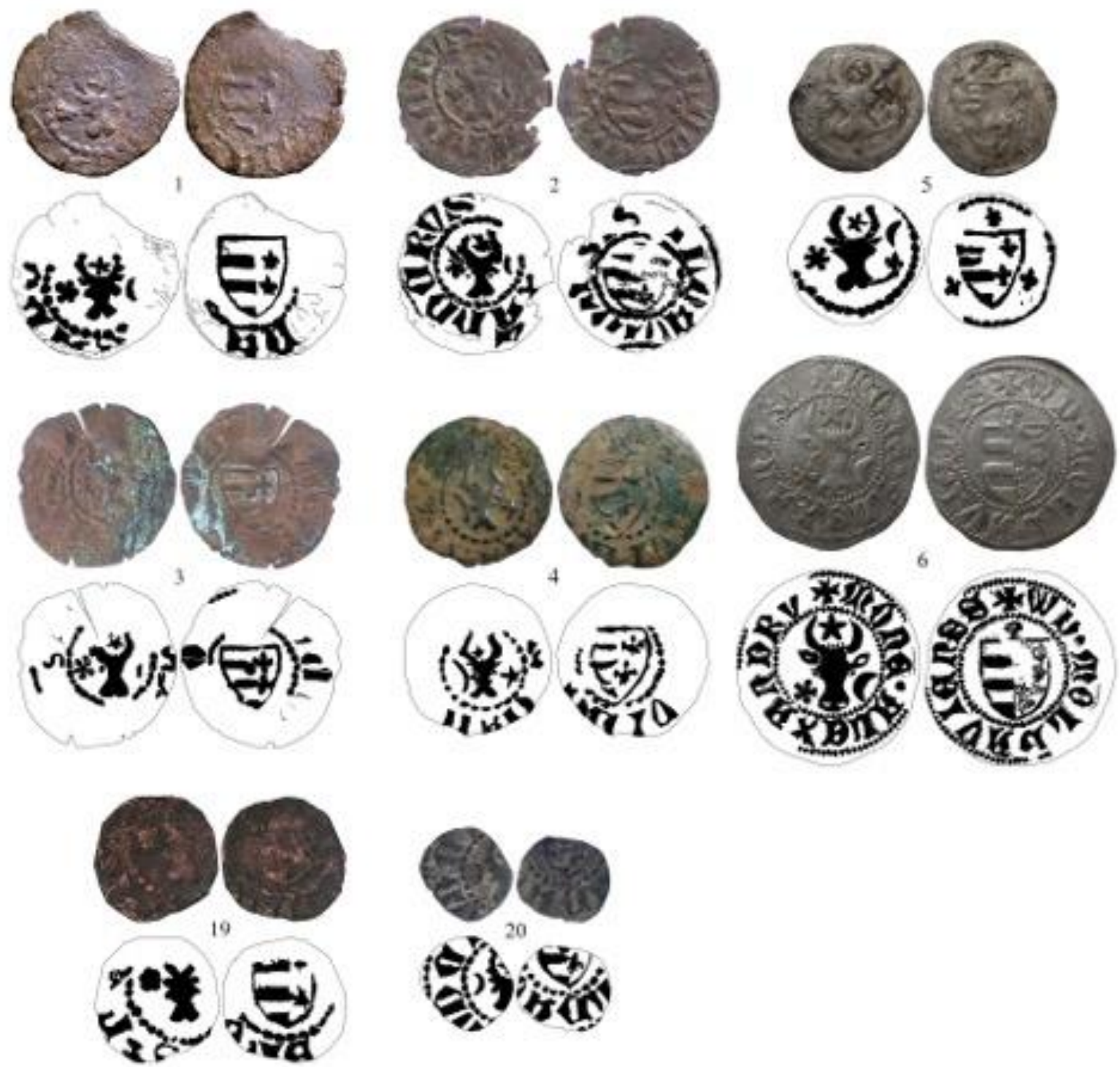

Рис. 1. 


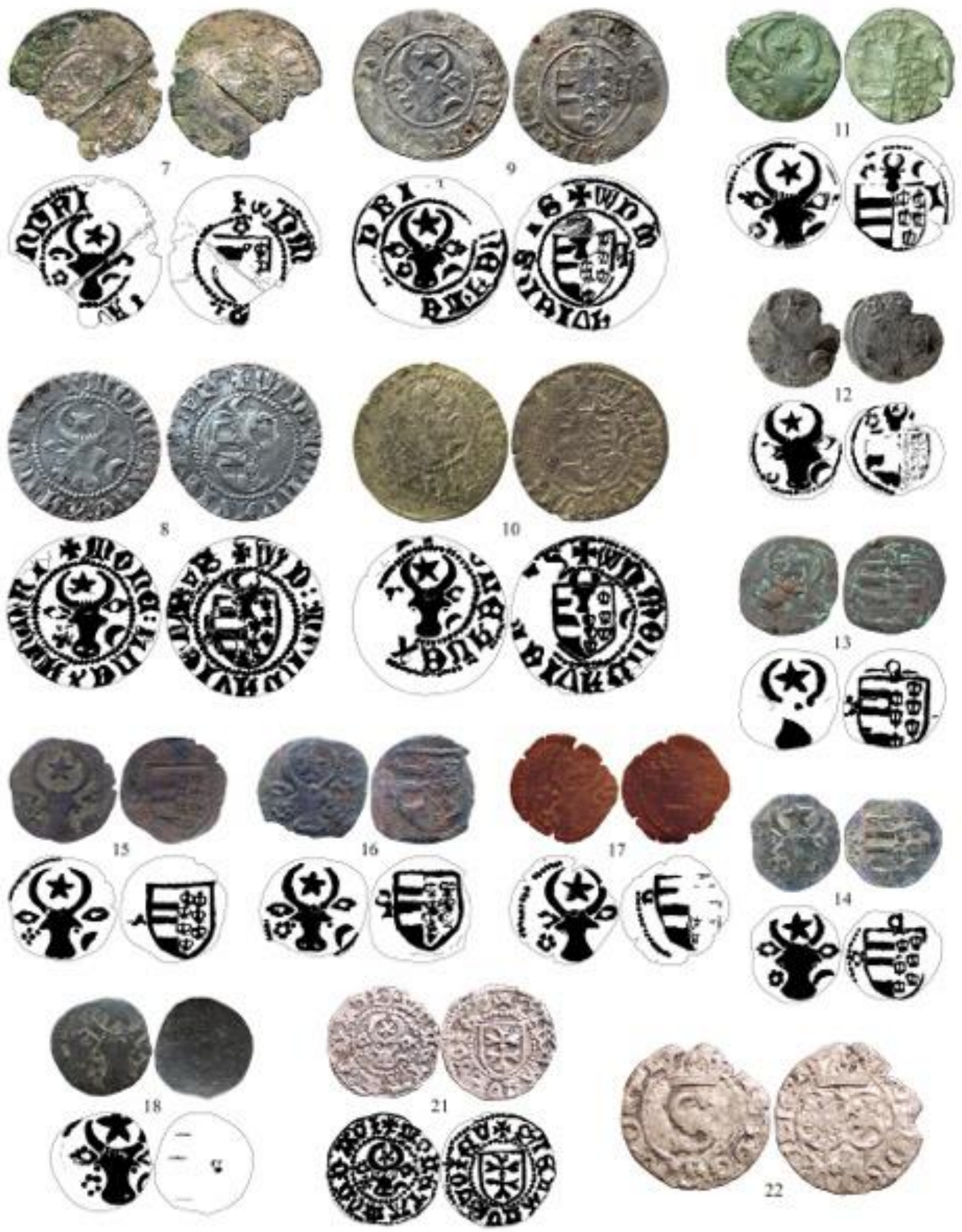

Рис. 2. 
The Ukrainian Numismatic Annual. Issue 5, Pereiaslav, 2021.

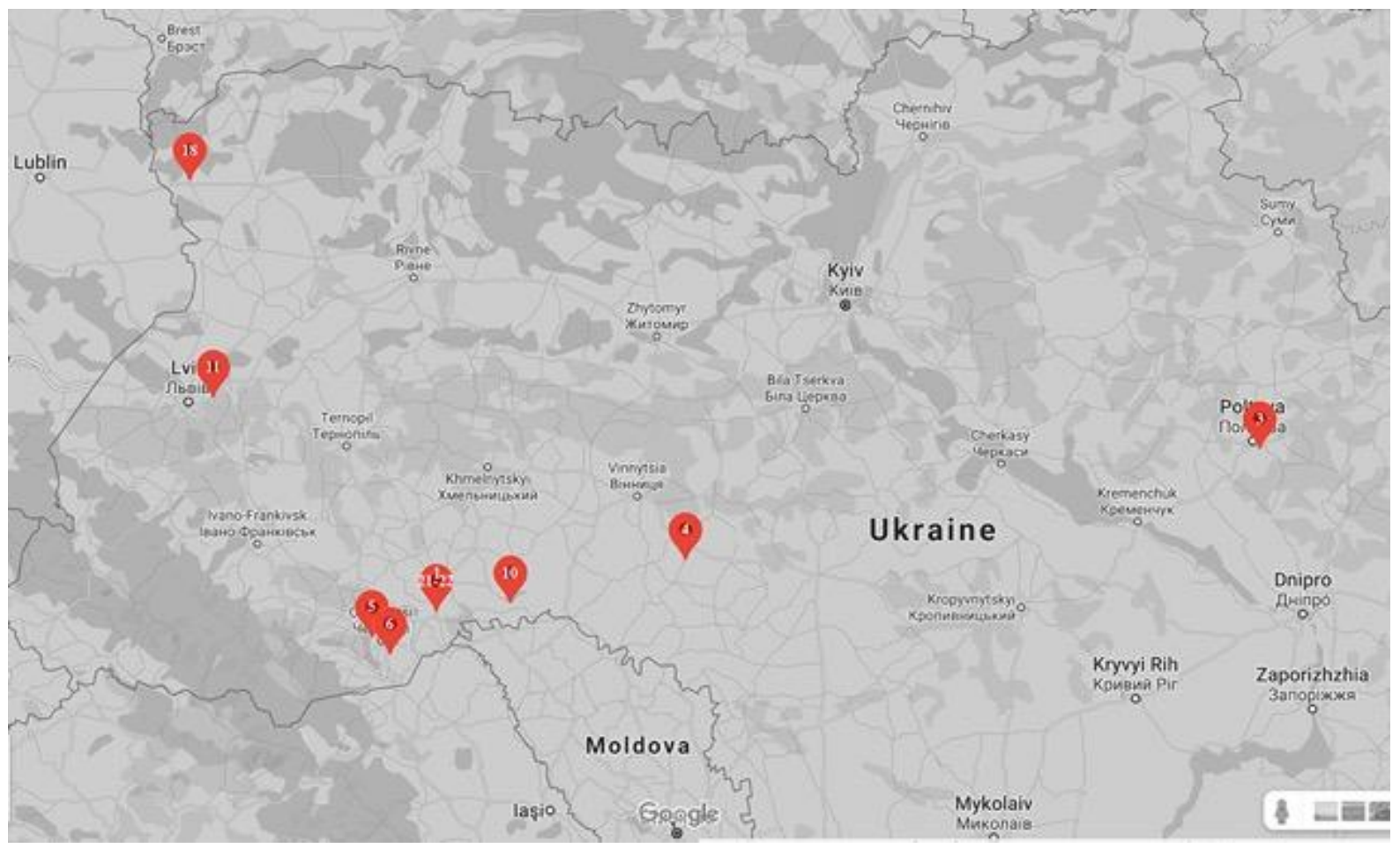

Рис. 3. 